\title{
DEVELOPMENT OF ALGORITHM FOR RISK ASSESSMENT OF THE LARGE RING ROAD CONSTRUCTION PROJECT AROUND KYIV
}

\section{РОЗРОБКА АЛГОРИТМУ ОЦІНЮВАННЯ РИЗИКІВ ПРОЕКТУ БУДІВНИЦТВА ВЕЛИКОӤ КІЛЬЦЕВОЇ АВТОМОБІЛЬНОЇ ДОРОГИ НАВКОЛО МІСТА КИЄВА}

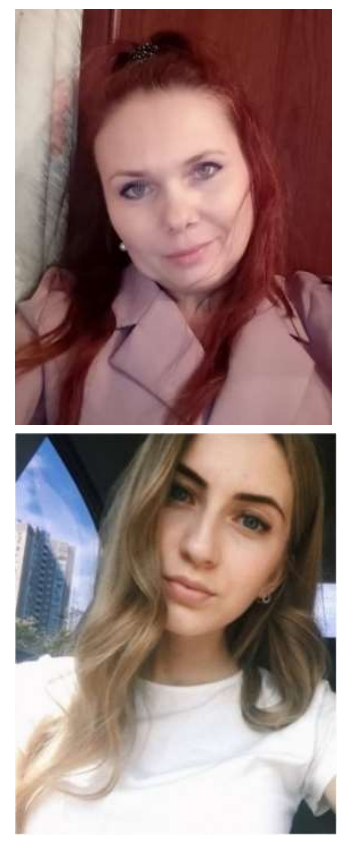

\begin{abstract}
Kharchenko Anna N., PhD (Cand. of Techn. Sciences), Associate Professor, National Transport University, Associate Professor of the Department of Transport Construction and Property Management e-mail: anna-x3@ukr.net, tel.+380442807909,
\end{abstract}

http://orcid.org/0000-0001-8166-6389

Summary. One of the most important areas of development in Ukraine is the road sector. It belongs to the strategic sectors of the national economy, and the public road network is a significant component of Ukraine's infrastructure potential. The length and condition of road affects not only the safety and quality, mobility and employment, accessibility of educational and other services, but also causes changes in the temp and flow of capital in Ukraine, and is a necessary prerequisite for recovery competitiveness of the country's economy as a whole.

Three international transport corridors pass through Ukraine, which are combined with four national transport corridors. They all pass through the Kyiv region. An urgent problem for Kyiv today is the construction of a Large Ring Road (hereinafter referred to as the "LRR") around Kyiv city, which should relieve the flow of transit transport through the capital of Ukraine, reduce harmful emissions from exhaust gases, and preserve the city roads from being destroyed by excessive vehicles, that are now creating a global city problem.

Key words: road sector, concession, large ring road, public-private partnership, evaluation.

Introduction. Starting from 2007, the project documentation for the construction of the LRR is being developed. The main objectives of the project are:

-strengthening the role of Ukraine as a transit country through the combination of three international and four national transport corridors; up to $40 \%$;

-unloading of Kyiv city from transit transport (average daily intensity of about 200 thousand cars / day),

-creating fast and comfortable conditions, improving road safety, significantly reducing travel time;

-development of a powerful infrastructure of the Kyiv region in a 500-meter corridor; 
-maintenance of the road network, which is not designed for heavy weight loads and requires considerable financial costs for its restoration;

-creation of jobs during and after the construction of the LRR, as well as in the roadside infrastructure (up to 30,000 places);

-use of products of domestic production of metallurgical, mining, oil, machine-building industries, etc.; -reducing congestion in Kyiv;

-increase of average operational speeds of traffic of vehicles, in comparison with the existing conditions of traffic through Kyiv;

$-4 \mathrm{x}$ reduction in traffic accidents due to poor road conditions;

-reduction of operating costs of road transport and unproductive costs of working hours of passengers and goods, reducing the cost of transportation;

-reduction of the negative impact on the environment, in particular, the amount of harmful emissions into the atmosphere by $40-50 \%$.

It should be noted that today, irrespective of the existing legislation on the allocation of land for construction, there are a number of problems, ranging from unauthorized construction in the 500-meter corridor, the allocation of land plots and the approval of project documentation for them and the development of design estimates.

Considering the development period of project documentation since 2007, in the current legislation of Ukraine there have been some changes in the part of state and departmental building norms and standards, and suspended the design.

The purpose of the study is to investigate the problematic issues related to the implementation of the construction of the Large Ring Road around Kyiv and the ways to solve them.

Main part. The design and construction of a Large Ring Road around Kyiv is based on the basis of the preliminary draft documentation for the construction of the LRR, developed in July 2007, which defines the general direction of the passage of the LRR, and was approved by the district state administrations in eight districts of Kyiv, Brovary, Boryspil, Vasylkiv, Vyshgorod, Kyiv-Svyatoshin, Makarov, Obukhov, the following physical volumes of work:

-route length $214 \mathrm{~km}$, including in the new direction $149 \mathrm{~km}$, on the existing roads - $65 \mathrm{~km}$;

-category of road - 1A (analogue of the Kyiv - Kharkiv-Dovzhansky road on the segment from Kharkovskaya Square, Kyiv to Boryspil Airport);

-intersections with highways at different levels, without traffic light regulation on the main route, providing speed calculation to $130 \mathrm{~km} / \mathrm{h}$;

-overpasses - 50;

-transport interchanges in two levels - 35;

-the number of lanes - 4-6;

-large bridge crossings - 3, incl. through the Dnipro River the northern junction - $8220 \mathrm{~m}$, the southern junction - 4900 m, through the Desna River - 8910 m;

-automated system for pavement condition, traffic control;

-external lighting;

-objects of road operational services - 9 units;

-objects of road service (parking, hotel, cafe, gas station, service station, car wash) - 42 units;

-estimated land area of about 2000 ha.

The total cost of the project works is 165 million UAH. Works for 130 million UAH have been completed. The need for funds to complete the project works is 35 million UAH.

Sources of funding provided by the project:

- State Budget of Ukraine (separate budget program);

- International Investor Loans (World Bank, EBRD, EIB, etc.); 
- Under concession (public-private partnership).

The investment return paths foreseen by the project:

- Fee for operational readiness (from the state budget);

- Revenues from the use of consumers of road service facilities;

- Revenues from payment for the travel of vehicles;

Potential participants in the project implementation are:

- State Road Agency of Ukraine;

- Kyiv Regional State Administration.

The problematic issue of the LRR construction is that the facts of unauthorized construction within the general direction of its passage have been revealed. In 2014, on the instructions of the Kyiv Regional State Administration, a survey was carried out to inspect and fix such sites of unauthorized construction. In order to carry out appropriate checks on such construction and take the necessary measures and restore the status of land plots, the Roads Service in the Kyiv region timely within its competence provided and agreed to provide complete and objective information in accordance with the developed materials for the design of the LRR, taking into account the documentation that also applies to land acquisition.

At present, the Department of Architectural and Construction Inspection in the Kyiv region and other obliged authorities need to accelerate the work on demolition and restoration of the status of land.

The General Directorate of the State Geocadastre in the Kyiv region provided information on the number of land plots in a 500-meter corridor on the first priority plot of construction of the projected LRR, namely partially or completely 1105 land plots, of which:

- Borodyansky district - 226 units;

- Makarov district - 418 units;

- Kyiv-Svyatoshinsky district - 228 units;

- Vasylkiv district - 163 units.

In 2009, the LRR is included in the list of objects that can be granted a concession under state guarantees. The mechanism for raising additional funds under state guarantees to finance the design and construction of the LRR should be defined to work on the involvement of international financial organizations in the financing of the preparation and implementation of LRR construction project.

Today, one of the main problems in the allocation of land for construction is that the current legislation does not provide for the possibility of automatic transfer of the right to use the land / lease when transferring ownership of real estate. The new owner actually has to go through the whole procedure of allotment of land to use and the conclusion of a lease, which in optimistic development can last about six months. However, the new owner cannot effectively use their property. There is no public access to state and communal property land databases, so investors cannot afford to be inspected from buildings (fig.1). Also, one of the problems is the improvement of the legislation on the use of agricultural land for road construction, the coordination of objects location. Overcoming all of the above issues affects the process of allotment of land for road construction and requires action as representatives of the road industry and legislation.

The concession for LRR construction involves the involvement of external investors. This form of project in the world was called "public-private partnership" [1]. PPP is a system of relations between public and private partners, in which the resources of both partners are combined with an appropriate allocation of risks, responsibilities and rewards (compensation) between them, for mutually beneficial long-term cooperation in the creation of new and / or modernization of existing the entities that need investment and in the use of such facilities [2]. 


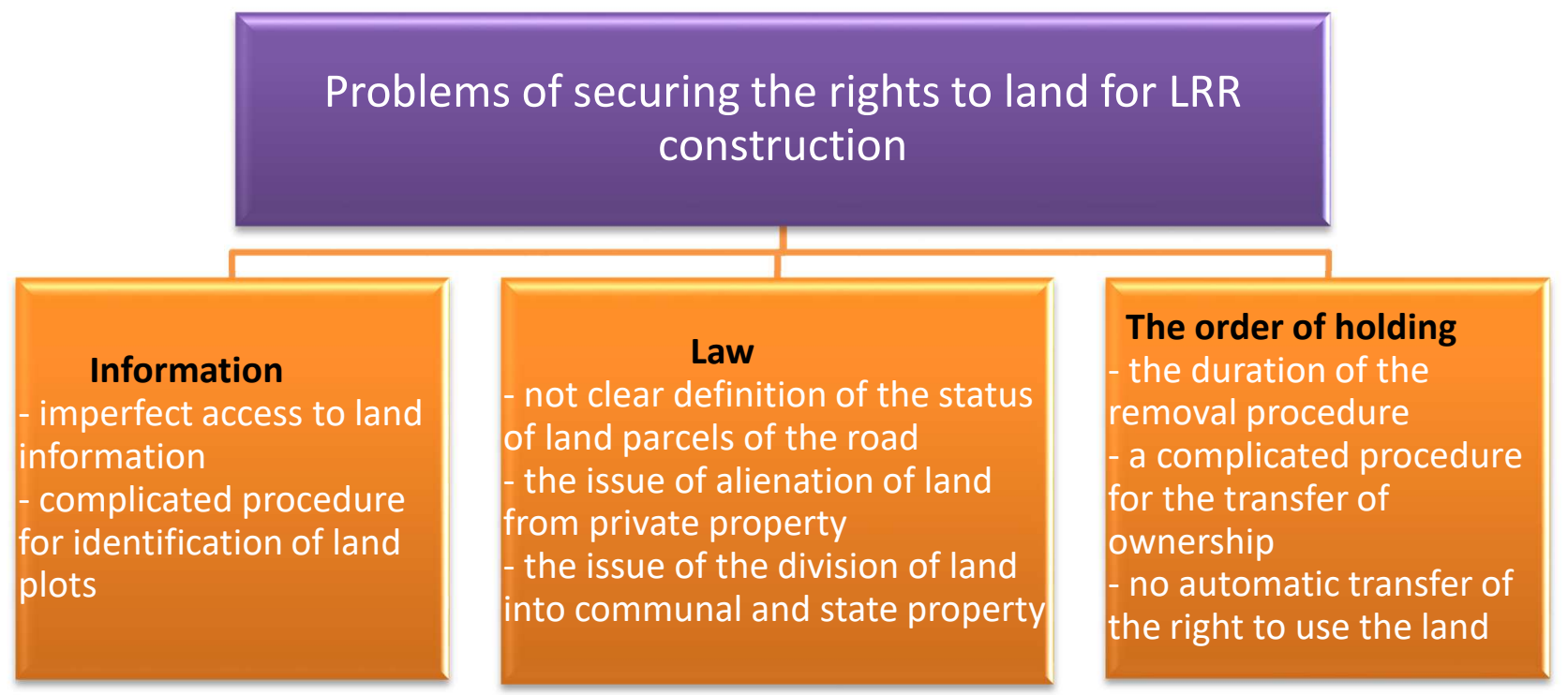

Figure 1 - Problems of securing the rights to land for LRR construction

Рисунок 1 - Проблеми забезпечення прав на земельні ділянки під будівництво ВКАД

Recently, public-private partnerships are gaining ground in Ukraine, as attracting investment, developing national, regional and local infrastructure, expanding and providing better services to citizens are undeniable public priorities [3-4].

Successful implementation of public-private partnership projects aimed at the development of infrastructure industries needs to be addressed in the various stages of the preparation and implementation process [2].

The main methods of valuation of PPP projects according to foreign experience in this research were Cost Benefit Analysis (CBA), methods of cost-effectiveness analysis of PPP projects (Cost Effective Analysis), multicriteria analysis (Multi-Criterion Analysis), methods of analysis of benefits and risks (Risk Benefit Analysis) [5].

The choice of a particular method depends on the amount of market information available regarding the expected income from owning (using) the property, the stability of its receipt, the purpose of the valuation and so on [6].

To analyze the effect of the implementation of the concession agreement was carried out by the method of benefit and risk analysis (Risk Benefit Analysis), which is used for project evaluation as a method of evaluating the effectiveness of investment projects implemented in the public sector, especially at the stage of "feasibility study", to support decision makers in choosing between design alternatives compared to financial and socio-economic indicators [7].

Risk Benefit Analysis compared the risks of situations and the cost of benefits during peer review.

Evaluating the risk group for the first phase of LRR construction from the M-06 Kyiv - Chop road to M-05 Kiev - Odessa a table with probability of occurrence of risk was prepared by the method of expert assessments (table 1). 
Table 1 - Risk grouping by cause

Таблиця 1 - Групування ризиків за причинами їх виникнення

\begin{tabular}{|c|c|c|c|}
\hline $\begin{array}{l}\text { Cluster risk / reasons } \\
\text { for risk }\end{array}$ & Risk groups & Types of risk / single risk & $\begin{array}{l}\text { Probability of occur- } \\
\text { rence, } \mathrm{Pi}\end{array}$ \\
\hline \multirow{6}{*}{ Political } & \multirow{3}{*}{ Changes in legislation } & changes in budget legislation & 0,04 \\
\hline & & changes in public policy & 0,04 \\
\hline & & changes in taxation & 0,03 \\
\hline & \multirow{2}{*}{ Budget changes } & budget restructuring & 0,015 \\
\hline & & budget constraints & 0,015 \\
\hline & $\begin{array}{l}\text { Changes in standards and } \\
\text { norms }\end{array}$ & $\begin{array}{l}\text { building standards and regulations } \\
\text { (state, industry) }\end{array}$ & 0,06 \\
\hline \multirow{7}{*}{ Contractual } & \multirow{3}{*}{ Contractual changes } & $\begin{array}{l}\text { changes in the general conditions of } \\
\text { the project }\end{array}$ & 0,13 \\
\hline & & anges in the form of the contract & 0,08 \\
\hline & & $\begin{array}{l}\text { unforeseen technical problems or en- } \\
\text { vironmental impact (environmental } \\
\text { risk) }\end{array}$ & 0,09 \\
\hline & \multirow[b]{2}{*}{ Related to a partner } & bankruptcy & 0,07 \\
\hline & & $\begin{array}{l}\text { refusal of the partner to perform the } \\
\text { work / ensure the required quality of } \\
\text { work }\end{array}$ & 0,05 \\
\hline & \multirow{2}{*}{$\begin{array}{l}\text { Changes in project imple- } \\
\text { mentation requirements }\end{array}$} & changes in user needs & 0,01 \\
\hline & & demographic / social changes & 0,07 \\
\hline \multirow{7}{*}{ Operational } & \multirow{2}{*}{ Natural } & significant rainfall & 0,04 \\
\hline & & natural disasters & 0,03 \\
\hline & \multirow[t]{2}{*}{ Productivity / quality } & $\begin{array}{l}\text { limiting the scope of modern tech- } \\
\text { nologies }\end{array}$ & 0,01 \\
\hline & & lack of resources & 0,08 \\
\hline & \multirow{3}{*}{ Management } & poor planning & 0,08 \\
\hline & & $\begin{array}{l}\text { shortcomings in the form of a con- } \\
\text { tract }\end{array}$ & 0,06 \\
\hline & & Total & 1 \\
\hline
\end{tabular}

The estimated length of new road will be $35.2 \mathrm{~km}$, the estimated cost of the project is 400 million UAH. The project is planned for 2020 .

Fare for $1 \mathrm{~km}$ will be charged 2.9 UAH, and for travel of the whole section - 102.08 UAH.

Risk Benefit Analysis includes determining the benefits of construction (B):

$$
\mathbf{B}=\mathbf{D} \times \mathbf{I} \times \mathbf{3 6 5},
$$

where D - revenue from the passage of one car on the whole road (102.08 UAH);

I - the intensity of cars per day (average daily intensity $\approx 40,000$ cars / day).

Determination of the cost of impact (C):

$$
\mathbf{C}_{\mathbf{i}}=\mathbf{P}_{\mathbf{i}} \times \mathbf{B},
$$


where $\mathrm{P}$ - probability of occurrence.

Determining the cost of risk $\left(\mathrm{R}_{\mathrm{i}}\right)$ :

$$
\mathbf{R}_{\mathbf{i}}=\mathbf{P}_{\mathbf{i}} \times \mathbf{C}_{\mathbf{i}}
$$

Determining the risk weight $\left(r_{i}\right)$ :

$$
r_{1}=\frac{R_{1}}{\sum_{i}^{n} R_{E, i}} \times 100
$$

Determining the risk of impact $(W)$ on construction

$$
W_{i}=r_{i} \times P_{i}
$$

The results of cost-risk calculations are presented in table 2 .

\begin{tabular}{|c|c|c|c|c|c|c|}
\hline № & $\begin{array}{c}\text { Types of risk / single } \\
\text { risk }\end{array}$ & $\begin{array}{l}\text { Probability of } \\
\text { occurrence }\left(\mathrm{P}_{\mathrm{i}}\right)\end{array}$ & $\begin{array}{l}\text { Determination of the } \\
\text { cost of impact }\left(\mathrm{C}_{\mathrm{i}}\right) \text {, } \\
\text { USD }\end{array}$ & $\begin{array}{c}\text { Determining the cost } \\
\text { of risk (Ri), } \\
\text { USD }\end{array}$ & $\begin{array}{c}\text { Determining } \\
\text { the risk } \\
\text { weight }\left(\mathrm{r}_{\mathrm{i}}\right)\end{array}$ & $\begin{array}{l}\text { Determining the } \\
\text { risk of impact } \\
\left(\mathrm{w}_{\mathrm{i}}\right)\end{array}$ \\
\hline 1 & 2 & 3 & 4 & 5 & 6 & 7 \\
\hline 1 & $\begin{array}{l}\text { changes in budget legis- } \\
\text { lation }\end{array}$ & 0,04 & 59614720,00 & 2384588,8 & 2,26 & 0,0902 \\
\hline 2 & changes in public policy & 0,04 & 59614720,00 & 2384588,8 & 2,26 & 0,0902 \\
\hline 3 & changes in taxation & 0,03 & 44711040,00 & 1341331,2 & 1,27 & 0,0380 \\
\hline 4 & budget restructuring & 0,015 & 22355520,00 & 335332,8 & 0,32 & 0,0047 \\
\hline 5 & budget constraints & 0,015 & 22355520,00 & 335332,8 & 0,32 & 0,0047 \\
\hline 6 & $\begin{array}{l}\text { building standards and } \\
\text { regulations (state, indus- } \\
\text { try) }\end{array}$ & 0,06 & 89422080,00 & 5365324,8 & 5,07 & 0,3044 \\
\hline 7 & $\begin{array}{l}\text { changes in the general } \\
\text { conditions of the project }\end{array}$ & 0,13 & 193747840,00 & 25187219,2 & 23,82 & 3,0965 \\
\hline 8 & $\begin{array}{l}\text { anges in the form of the } \\
\text { contract }\end{array}$ & 0,08 & 119229440,00 & 9538355,2 & 9,02 & 0,7216 \\
\hline 9 & $\begin{array}{l}\text { unforeseen technical } \\
\text { problems or environ- } \\
\text { mental impact (environ- } \\
\text { mental risk) }\end{array}$ & 0,09 & 134133120,00 & 12071980,8 & 11,42 & 1,0274 \\
\hline 10 & bankruptcy & 0,07 & 59614720,00 & 7302803,2 & 6,90 & 0,4834 \\
\hline 11 & $\begin{array}{l}\text { refusal of the partner to } \\
\text { perform the work / en- } \\
\text { sure the required quality } \\
\text { of work }\end{array}$ & 0,05 & 74518400,00 & 3725920,0 & 3,52 & 0,1761 \\
\hline
\end{tabular}

Table 2 - The results of cost-risk calculations

Таблиця 2 - Результати розрахунків за методом витрати-ризики 
Continued table 2

\begin{tabular}{|c|c|c|c|c|c|c|}
\hline 1 & 2 & 3 & 4 & 5 & 6 & 7 \\
\hline 12 & changes in user needs & 0,01 & 14903680,00 & 149036,8 & 0,14 & 0,0014 \\
\hline 13 & $\begin{array}{l}\text { demographic / social } \\
\text { changes }\end{array}$ & 0,07 & 104325760,00 & 7302803,2 & 6,90 & 0,4834 \\
\hline 14 & significant rainfall & 0,04 & 59614720,00 & 2384588,8 & 2,26 & 0,0902 \\
\hline 15 & natural disasters & 0,03 & 44711040,00 & 1341331,2 & 1,27 & 0,0380 \\
\hline 16 & $\begin{array}{l}\text { limiting the scope of } \\
\text { modern technologies }\end{array}$ & 0,01 & 14903680,00 & 149036,8 & 0,14 & 0,0014 \\
\hline 17 & lack of resources & 0,08 & 119229440,00 & 9538355,2 & 9,02 & 0,7216 \\
\hline 18 & poor planning & 0,08 & 119229440,00 & 9538355,2 & 9,02 & 0,7216 \\
\hline 19 & $\begin{array}{l}\text { shortcomings in the } \\
\text { form of a contract }\end{array}$ & 0,06 & 89422080,00 & 5365324,8 & 5,07 & 0,3044 \\
\hline & $\sum$ & 1 & 1445656960,00 & 105741609,6 & 100,00 & 8,3999 \\
\hline
\end{tabular}

Conclusions: According to the Risk Benefit Analysis method for construction of a Large Ring Road around Kyiv, the effect of the implementation of the concession agreement amounted to $353.01 \%$, which in monetary terms 510331363 449,6 USD. The payback period of the project is four years. We propose to set a certain risk of influence on road construction in the fare, which will accordingly amount to $110.65 \mathrm{UAH}$.

\section{References}

1. Про державно - приватне партнерство: Закон України від 01.07.2010 №2404-VI. - [Електронний ресурс]. - Режим доступу: http://zakon4.rada.gov.ua/laws/show/2404-17.1.

2. Деякі питання організації здійснення державно-приватного партнерства : Постанова Кабінету Міністрів України № 384 від 11 квітня 2011 р. / Кабінет Міністрів України // Офіційний вісник України : [Електронний ресурс]. - Режим доступу : http://www.kmu.gov.ua.

3.KatalinTánczos, GiSeogKong. Public-Private PartnershipInfrastructure Projects // Periodica polytechnica ser. Transp. Eng. Vol. 29, 2001. - No. 1-2, pp. 71-81.

4. Canada Strategic Infrastructure Fund Act, 2002, c. 9, s. 47, [Assented to March 27th, 2002]; Regulations Prescribing Capital Assets for the Purpose of the Definition "Strategic Infrastructure" in the Canada Strategic Infrastructure Fund Act SOR/2003-51Registration January 30, 2003.

5. Green Paper on public-privatepartnerships and Community law on public contracts and concessions, presented by the Commission of the European Communities, Brussels, 30.4.2004 COM(2004) 327 final.

6. Gutachten des Bundesbeauftragten für Wirtschaftlichkeit in der Verwaltung zu Wirtschaftlichkeitsuntersuchungen bei Öffentlich Privaten Partnerschaften (ÖPP) im Bundesfernstraßenbau // Gz. V 3 - 2013 0144 Bonn, 2013.10.SIMULATION OF INVESTMENT RETURNS OF TOLL PROJECTS / by Weiyuan Yuwen, Zhanmin Zhang // Texas A\&M Transportation Institute, August 2013.

7. David, Rodreck; Ngulube, Patrick; Dube, Adock (16 July 2013). A cost-benefit analysis of document management strategies used at a financial institution in Zimbabwe: A case study. SA Journal of Information Management. 15 (2).

\section{РОЗРОБКА АЛГОРИТМУ ОЦІНЮВАННЯ РИЗИКІВ ПРОЕКТУ БУДІВНИЦТВА ВЕЛИКОЇ КІЛЬЦЕВОЇ АВТОМОБІЛЬНОЇ ДОРОГИ НАВКОЛО МІСТА КИЄВА}

Харченко Анна Миколаївна, кандидат технічних наук, доцент, Національний транспортний університет, доцент кафедри транспортного будівництва та управління майном, e-mail: anna-x3@ukr.net, tel. +380442807909, Україна, 01010, м. Київ, вул. М. Омеляновича-Павленка, 1, к. 206. https://orcid.org/00000001-8166-6389 
Котик Дар'я, Київська обласна державна адміністрація, Департамент регіонального розвитку Київської обласної державної адміністрації, Управління функціонування та розвитку автомобільних доріг загального користування місцевого значення, головний спеціаліст відділу інноваційно-концесійної роботи, e-mail: kotikdasha97@gmail.com, tel. +380956103828, Україна, 02000, м. Київ, вул. Юрія Ільєнка, 40, к. 510. https://orcid.org/0000-0003-1960-5029

Анотація. Одним з найголовніших напрямів розвитку в Україні $є$ дорожнє господарство. Воно належить до стратегічних галузей національної економіки, а мережа автомобільних доріг загального користування $\epsilon$ вагомою складовою інфраструктурного потенціалу України. Протяжність та стан автодоріг впливає не тільки на безпеку та якість перевезення вантажів та пасажирів, мобільність та рівень зайнятості населення, доступність освітніх та інших послуг, а й обумовлює зміну темпів та потоків руху капіталу в Україні та за ії межами, а також $є$ необхідною передумовою відновлення конкурентоспроможності економіки країни в цілому.

Через Україну проходять три міжнародних транспортні коридори, які поєднуються з чотирма національними транспортними коридорами. Всі вони проходять через Київську область. Актуальною проблемою для Києва на сьогодні є будівництво великої кільцевої автомобільної дороги навколо міста Києва, яка має розвантажити потік транзитного транспорту через столицю України, зменшити шкідливі викиди від вихлопних газів, зберегти покриття доріг у місті від руйнування через надмірну кількість транспортних засобів, що зараз створюють глобальну проблему місту. Переоцінити значення ВКАД не можливо, вона має стратегічне значення для всієї країни, а ось її відсутність навпаки - завдає великої шкоди та приносить багатомільйонні збитки місту Києву та ії мешканцям.

Ключові слова: дорожня галузь, концесія, велика кільцева автомобільна дорога, державно-приватне партнерство, оцінка.

\section{Перелік посилань}

1. Про державно - приватне партнерство: Закон України від 01.07.2010 №2404-VI. - [Електронний ресурс]. - Режим доступу: http://zakon4.rada.gov.ua/laws/show/2404-17.1.

2. Деякі питання організації здійснення державно-приватного партнерства : Постанова Кабінету Міністрів України № 384 від 11 квітня 2011 р. / Кабінет Міністрів України // Офіційний вісник України : [Електронний ресурс]. - Режим доступу : http://www.kmu.gov.ua.

3.KatalinTánczos, GiSeogKong. Public-Private PartnershipInfrastructure Projects // Periodica polytechnica ser. Transp. Eng. Vol. 29, 2001. - No. 1-2, pp. 71-81.

4. Canada Strategic Infrastructure Fund Act, 2002, c. 9, s. 47, [Assented to March 27th, 2002]; Regulations Prescribing Capital Assets for the Purpose of the Definition "Strategic Infrastructure" in the Canada Strategic Infrastructure Fund Act SOR/2003-51Registration January 30, 2003.

5. Green Paper on public-privatepartnerships and Community law on public contracts and concessions, presented by the Commission of the European Communities, Brussels, 30.4.2004 COM(2004) 327 final.

6. Gutachten des Bundesbeauftragten für Wirtschaftlichkeit in der Verwaltung zu Wirtschaftlichkeitsuntersuchungen bei Öffentlich Privaten Partnerschaften (ÖPP) im Bundesfernstraßenbau // Gz. V 3 - 2013 0144 Bonn, 2013.10.SIMULATION OF INVESTMENT RETURNS OF TOLL PROJECTS / by Weiyuan Yuwen, Zhanmin Zhang // Texas A\&M Transportation Institute, August 2013.

7. David, Rodreck; Ngulube, Patrick; Dube, Adock (16 July 2013). A cost-benefit analysis of document management strategies used at a financial institution in Zimbabwe: A case study. SA Journal of Information Management. 15 (2). 